\section{Youth violence in Latin America: current situation and violence prevention strategies}

\author{
Katherine Weaver ${ }^{1}$ and \\ Matilde Maddaleno ${ }^{2}$
}

During the last few decades, there has been a considerable increase in the level of violence witnessed throughout the world. Violence has reached epidemic proportions and become one of the most serious public health problems facing the Region of the Americas. In 1993 alone, in Latin America and the Caribbean, 465000 deaths due to violent acts were reported, or approximately 1250 deaths per day. In fact, mortality rates from external causes (homicides, suicides, traffic accidents, and other injuries) have begun to affect the general mortality rate significantly. The situation is particularly alarming among adolescents and youth (1). The Pan American Health Organization (PAHO) and the World Health Organization (WHO) define adolescence as the period between 10 and 19 years of age and youth as the period between 15 and 24 years. The adolescent population represents $20.3 \%$ of the entire population in the Region of the Americas. Together, adolescents and youth make up $31.6 \%$ of the total population of the Americas (2).

Of the total homicides in the Region, some $28.7 \%$ of them occur among persons aged 10-19. Homicide is the second leading cause of death in this age group in 10 of the 21 countries of the Region with populations greater than one million, and it's one of the five leading causes of death in 17 of the 21 countries (3).

In the Americas, the highest mortality rates due to homicide occur in young men aged 15 to 24 (4). Countries in the Region with the highest homicide rates among these young men are Colombia (267 per 100 000), Puerto Rico (93 per 100000$)$, Venezuela (69 per 100000 ), and Brazil (72 per 100000 ). Countries with an intermediate mortality rate for males aged 15 to 24 are Mexico (41 per 100000$)$, the United States of America (38 per 100000$)$, Panama (32 per 100 000), Ecuador (26 per 100000$)$, and Trinidad and Tobago (21 per 100000$)$ (5).

The problem of gang violence is increasing in many countries of the Region $(6,7)$. For example, in Cali, Colombia, youth gangs committed about $10 \%$ of the homicides during the first six months of 1993. In 1994, there were 1500 gangs in Mexico City, and the same number were reported in Guayaquil, Ecuador (7). According to the 1997 Caribbean Adolescent Health Survey, one out of 11 adolescents reported they belonged to a gang and an additional $10 \%$ said they had in the past. One out of nine of 
those $16-18$ years old reported having been in a fight where weapons were involved within the preceding year; an additional $4 \%$ had used weapons in fights three or more times. Young persons in a gang are more likely to consume alcohol, fight with weapons, smoke marijuana, have sexual relations, and express extreme anger (6).

The premature death of young people due to violence results in high economic and social costs. Violence is the primary cause of potential years of life lost (PYLL) ${ }^{3}$ among adolescents and youth in the majority of the countries in the Region of the Americas, resulting in an average loss of 30 to 40 years per death (2). The direct economic cost of death and disability as a result of violent acts is estimated at $\$ 10$ billion annually. This represents approximately $20 \%$ of the total national expenditure on health in the countries of the Region (1).

Deaths due to violence, however, constitute only a small portion of the total problem. PAHO estimates that for every child and adolescent that dies due to trauma, 15 are left severely injured by violence (2).

Latin America has no systematic registry of nonlethal forms of violence. In the majority of the countries of the Region, no epidemiological surveillance systems have been implemented to monitor violent acts. Nevertheless, results from isolated research studies demonstrate the frequency and significance of these types of injuries that, although not fatal, determine the conditions, quality of life, and future for adolescents and youth affected.

Adolescents are one of the populations most affected by violence in all of its forms. Violence during adolescence is not limited to physical injury, but also includes sexual abuse, neglect, emotional and verbal abuse, threats, sexual assault, and other forms of psychological abuse (8). According to the Caribbean Adolescent Health Survey, by the age of 16 to 18 , one in five young people had been physically abused (6).

High rates of sexual abuse and incidence of rape, especially among the youngest adolescent females, are only beginning to be reported in Latin America and the Caribbean (9). The Caribbean Adolescent Health Survey found that by 16-18 years old, one in eight adolescents had been sexually abused; females were twice as likely as males to be the victims of such abuse (6). Adolescent girls are especially vulnerable to violence of all kinds because of their relative lack of power-physically,

\footnotetext{
3 Potential years of life lost due to a particular cause is the overall sum of the years lost to premature death, as compared to the additional years these persons would have lived had they experienced normal life expectancy.
}

socially, and economically. Young people are increasingly being exploited as sex partners based on the assumption that they are less likely to have a sexually transmitted disease or to be HIV positive (8). Sexual abuse has been linked to other behavioral problems, including excessive use of alcohol and other drugs, unprotected sex with multiple partners, and prostitution (8).

Young people are also vulnerable to the kinds of stress that promote mental instability, with disorders of social development very common. Although their implications for subsequent ill health have not been thoroughly studied in developing countries, such disorders are likely to have a substantial impact (10), which is partly reflected in the high incidence of depression, abuse of alcohol and other substances, and other high-risk behaviors (11).

Another manifestation of these mental disorders is the incidence of mortality due to suicides in adolescents and youth. Such deaths are often underreported because of the cultural stigma associated with taking one's own life. Rates are usually higher for male adolescents than females. However, in Cuba, suicide rates are higher for adolescent females (4).

In the Region of the Americas, $18 \%$ of suicides are attributed to persons aged 15 to 24 (3). Countries with the highest suicide rates for males in this age group are, in descending order: Canada, the United States, El Salvador, Trinidad and Tobago, Cuba, Uruguay, and Venezuela (5). The Caribbean Health Survey reported that $10 \%$ of those 10-12 years old, $17 \%$ of those $13-15$, and $23 \%$ of those 16-18 years reported that a friend had attempted or completed suicide. There is a very high correlation between an adolescent committing suicide and a friend's attempted suicide. Teens who have a friend commit suicide are three to four times more likely to commit suicide themselves (6).

Adolescents and youth in the Region of the Americas are exposed to a great deal of violence through the mass media. Currently, a consensus exists that this exposure is one of the reasons for aggressive behavior, crimes, and other violence among young people. Although it does not constitute the sole cause of violence, the influence of the media is one of the contributing factors that can most feasibly be controlled (12).

Adolescents are not only victims of violence; they are also perpetrators or intermediaries of various acts of violence. Violent acts affect victims directly, as well as their families, classmates, colleagues, and the rest of the community. All forms of violence have damaging short- and long-term effects on the physical and mental health of those involved. Furthermore, violent acts generate enor- 
mous costs to society in health care and diminished productivity.

Violence among adolescents and youth is avoidable and preventable (13). Individual characteristics, family experiences, access to weapons, alcohol and drug use, exposure to violence in the media, and other political, cultural, and social factors are all interrelated and play a fundamental role in the incidence of violence among young people. Given its multifaceted nature, violence should be prevented through the coordinated and active participation of all sectors, with a multidisciplinary focus.

\section{LESSONS LEARNED FROM VIOLENCE PREVENTION STRATEGIES}

The PAHO Adolescent Health Program of the Division for Health Promotion and Protection recently published a document on violence prevention entitled "Juvenile violence in the Americas: innovative studies in research, diagnosis, and prevention," which was written by Alfred McAlister (14). The following section summarizes the literature review on lessons learned in youth violence prevention from this report. Emphasis was placed on discussing approaches that are currently being implemented in many countries but often without adequate evaluations of their effectiveness. Some common strategies in violence prevention have demonstrated their usefulness while others must be reevaluated based on empirical evidence.

Violence prevention usually involves one of four approaches. These are: 1) reducing the availability of firearms and other instruments for excessively violent responses, 2) decreasing the extent of conflict situations or events, 3) changing consequences so as to punish violence and reward nonviolence, and 4) modeling communication in order to modify psychosocial processes, change attitudes, and teach skills. The first three approaches take in policies and programs to change the constraints and opportunities in the environment. The fourth option involves education and communication campaigns targeting parents, schools, and communities.

\section{Reducing the availability of firearms}

Firearms availability is a major factor influencing death rates from violence. Public health experts have repeatedly recommended reducing the access to handguns (14). In Latin America, technological advances in personal and military hardware have also increased the destructiveness of armed conflict.
Evidence from a recent study in Cali, Colombia, demonstrated that handgun control could reduce homicide rates. In 1993, the city implemented a policy of "personal disarmament" during certain times of the day in high-risk areas. Carrying firearms was prohibited evenings and nights during the weekend, and police had the authority to search for weapons. Residents supported the policy because of widespread fear of shooting. The policy reduced firearm deaths by $20 \%$ (15). In the United States, similar disarmament policies are in place at schools (16). There is little doubt that limits on firearm possession can reduce risks of intentional and accidental death among young people (15).

\section{Reducing conflict}

Poverty is often related to youth aggression because of increased stress and feelings of hopelessness that may arise from chronic unemployment (17). Interventions that reduce poverty and increase hope can reduce the incidence of violence during childhood and adolescence (18). Improvements in education can also reduce the risk of violence among youth. In the recent Caribbean Health Survey, teenagers with difficulty learning in school were more likely to fight with weapons and attempt suicide (6).

In many cities of the Americas, programs to reduce conflict have been established that focus on improving the quality of life and economic opportunities. One example from Cali, Colombia, included legalization of home ownership for squatters, microenterprise training for small businesses, and provision of health care, recreational facilities, and other services. Better street lighting enhanced safety. Neighborhood development reduced recruitment to gangs. Over a several-year period, conditions improved in the neighborhoods where the activities were implemented (14).

\section{Modifying consequences of violent behavior}

Another method to reduce violence is to increase the enforcement of legal and police protection. Sherman, Shaw, and Rogan demonstrated that crime could be reduced by $50 \%$ when police activity in high crime areas was increased (19). In Latin America, confidence in police in many cities is low and there are attempts underway to upgrade the quality of law enforcement (14).

In Boston, there was an effort to improve policing and the criminal justice system to combat the problem of youth gang violence. Gang members 
learned that the consequences of violent behavior would be certain. An entire gang was jailed and its headquarters destroyed. While all the long-term effects of the intervention are unknown, shooting deaths among young African-American men decreased by more than a half. Therefore, it appears that coordinated law enforcement and judicial activity can significantly reduce gang violence among urban youth (15).

Incarceration of youth may not have the desired effect of reducing violent crime. Feldman (20) found that delinquency is reduced more dramatically when misbehaving youth are grouped with well-behaving peers rather than just incarcerated with each other. In one case, several groups of youth went through a behavior modification program to change perceived group norms. In a mixed group, $91 \%$ of the boys showed a decrease in antisocial behavior whereas only $51 \%$ of those in the segregated groups showed similar improvements. None of the well-behaving youths demonstrated antisocial behavior after being mixed with young men with antisocial behavior. This study demonstrates the need to find alternatives to institutional segregation for violent youth.

\section{Programs for parents}

Violence from parents towards children is especially important because children who are victims tend to become perpetrators later in life (21). An extensive literature review on parent training demonstrated that training parents in less coercive discipline led to less violence among their children $(22,23)$. One study examined simultaneous parent and child training and found that the best results came from a combined approach (24). Programs for families in crisis have also reduced youth violence by helping youths stay with their families (20). Marital and family counseling can reduce fighting in the family and delinquency among children (14).

Another approach is to teach parenting skills to young people in school before they become parents. Zoline and Jason (25) reported that such programs could produce changes in knowledge and expectations among young men and women, although effects on behavior and skills were small.

In the United States, coercive and dysfunctional parenting behaviors are most prevalent among families with the lowest incomes. Patterson, DeBaryshe, and Ramsey (26) found that the effect that low socioeconomic status has on antisocial behavior is due to poor family functioning. They suggest skills training to change social norms regard- ing the acceptability of spanking and other harsh punishment. Programs to improve parenting and enhance the quality of family life offer hope for preventing violence among children and youth where economic disparities are not decreasing (26).

\section{School-based programs}

According to McAlister, the literature demonstrates that positive effects can be achieved through school-based environmental changes and from educational activities to change attitudes and teach skills. In the United States, a program in the state of New Mexico called "Peace Builders" provided students with models of good behavior. The program taught five principles: praise others, don't insult people, seek wise advisors, notice and correct hurts, and right wrongs. Students who displayed the desired behaviors were recognized over the public address system. While rates of fighting-related injury remained unchanged in the program schools, they increased by $20 \%$ in the control schools (27).

Another strategy has been the use of peer mediators to resolve conflicts. Although most studies show no clear effects, one randomized study by Tolson, McDonald, and Moriarty (28) found that repeated problems in discipline were significantly lower in students referred to peer counseling. However, mentoring programs that paired young people with college student or adult volunteers had no demonstrated effects on youth violence (14). Hawkins and Catalano have developed a program entitled "Communities that Care" that combines school and community programs to increase protective factors and decrease risk factors. Studies from the program have demonstrated improvements in academic performance, as well as preventive effects against delinquency and alcohol consumption (14).

The Carnegie Corporation is currently conducting research on school-based communication campaigns to change attitudes and reduce ethnic violence between Hispanics and African-Americans. The project is working in a school that has been the site of race riots. Students tell stories about how they have improved group relations and changed attitudes about conflict resolution. Students also present real stories about changing attitudes towards the use of firearms and the right to kill to settle differences between ethnic groups and nationalities. Publicity generated by news coverage also informs parents and the rest of the community about the project. The proportion of young men endorsing the right to kill to defend property fell from $69 \%$ to $52 \%$ in the program school (29). 


\section{Community and media campaigns}

Although many have called for community campaigns, the majority of education and communication efforts have occurred in school settings (30). Given the previously mentioned influence of the mass media on young people, prevention campaigns need to provide new media images or new scripts for dealing with violence. At a 1996 PAHO meeting in Cartagena, Colombia, sponsored by the Organization's Health Promotion and Protection Division, social scientists, public health leaders, and journalists debated the need for new policies to limit the portrayal of violence in news and entertainment. Much of the discussion centered around the themes and roles for violence that are contained in imported dramatic and reality programs (31).

An extensive media campaign is part of a community experiment being conducted at the University del Valle in Cali, Colombia. Using the approach known as "behavioral journalism," stories are told in which residents of high-violence neighborhoods describe their own decisions to reject violence and learn skills to resolve conflicts. Stories model appropriate parenting skills and rejection of punitive child discipline. In "street radio" programs, young people also express their desire for peace and portray strategies for resolving conflicts. Although the project evaluation is not complete, initial evidence demonstrates that the program has had at least one apparent effect. Neighborhoods previously known mostly for murder and other violent crimes are now seen by their residents and other persons as communities in which many people avoid violence (32).

\section{CONCLUSION}

Although youth violence is quite complex, it can be understood and potentially prevented through several approaches based on theoretical concepts and principles. Policies can reduce access to guns. Violence against children and youth can be prevented by improving education, employment opportunities, and the quality of life and by enhancing relations among different ethnic groups. The consequences of violent behavior should be modified through changes in law enforcement and the judicial system. School- and communitylevel communication and parenting education can change attitudes and skills in violence prevention among young people and adults. This public health approach to violence prevention emphasizes the need for several strategies to address multiple causes simultaneously in entire populations.

\section{SINOPSIS}

\section{La violencia entre la juventud en América Latina: situación actual y estrategias para su prevención}

La violencia, que ha adquirido proporciones endémicas, se ha convertido en uno de los problemas de salud pública más graves que aquejan a la Región de las Américas. La situación es más alarmante aun entre los adolescentes y la juventud, es decir, entre las personas de 10 a 24 años de edad. En este artículo se examinan la situación actual de la violencia y las lecciones aprendidas a partir de las estrategias aplicadas actualmente para prevenir la violencia entre la juventud. El artículo, donde se aplica un enfoque de salud pública para la prevención de la violencia, hace hincapié en la necesidad de aplicar diversas estrategias en poblaciones enteras a fin de explorar de forma simultánea numerosas causas.

Según los resultados de una revisión bibliográfica de Alfred McAlister, la violencia contra la gente joven puede prevenirse si se limita el acceso a armas de fuego, si se mejoran la calidad de la vida y las oportunidades de empleo y educación, y si se fomentan mejores relaciones entre los distintos grupos étnicos. Las consecuencias de las conductas violentas pueden modificarse más eficazmente mediante cambios en el sistema de imposición de la ley y en el sistema judicial que mediante la habitual estrategia de encarcelar al joven. Las comunicaciones en la escuela y la comunidad, así como la educación de los padres de familia, pueden cambiar la actitud de las personas jóvenes y mejorar su capacidad para prevenir la violencia.

\section{REFERENCES}

1. Pan American Health Organization. Memoirs of the Inter-American Conference on Society, Violence and Health. Washington, D.C.: PAHO; 1996.

2. Pan American Health Organization. Health conditions in the Americas. 1994 ed. Washington, D.C.: PAHO; 1994. (Scientific Publication 549; $1 \mathrm{vol}$ ).

3. Maddaleno M, Munist M, Serrano C, Silber T, Yunes J. La salud del adolescente y joven. Washington, D.C.: PAHO; 1995. (Scientific Publication 552).
4. Yunes J, Zubarew T. Mortality from violent causes among adolescents and young people: a challenge for the Region of the Americas. Washington, D.C.: PAHO; 1997.

5. Adolescent program health situation analysis [mortality database from Pan 
American Health Organization Technical Health Information System]. Washington, D.C.: PAHO; 1996.

6. Pan American Health Organization. Caribbean Adolescent Health Survey: Antigua, Dominica, Grenada, Jamaica. Barbados: PAHO; 1998.

7. Pan American Health Organization. Workshop on Violence and Adolescent and Youth Gangs. Washington, D.C.: PAHO; 1997.

8. Heise L. Violence against women: the hidden health burden. Washington, D.C.: The World Bank; 1994

9. United Nations Children's Fund. The state of the world's children 1997. New York: UNICEF; 1997.

10. United Nations Children's Fund. Youth health for a change: a UNICEF notebook on programming for young people's health and development. New York: UNICEF; 1997.

11. Florenzano R. Revista EDISA No. 12: Mental Health of Adolescents [module from distance education course]. Buenos Aires, Argentina: Facultad de Medicina, Universidad de Buenos Aires; 1997.

12. American Academy of Pediatrics, Committee of Communications. Media violence. Pediatrics 1995;95(6):949-951.

13. Eron LD, Gentry JH, Schlege P. Reason to hope, a psychosocial perspective on violence and youth. Washington, D.C.: American Psychological Association; 1994.

14. McAlister A. Juvenile violence in the Americas: innovative studies in research, diagnosis, and prevention. Washington, D.C.: Pan American Health Organization, Division of Health Promotion and Protection, Adolescent Health Unit; 1999.

15. Guerrero R, McAlister A, Concha Eastman A, Espitia VE. Personal disarma- ment deters homicide in Cali, Colombia [unpublished report]. Cali, Colombia; 1995.

16. Ginsberg D, Loffredo L. Violencerelated attitudes and behaviors of high school students-New York City, 1992. MMWR Morb Mortal Wkly Rep 1993; 42(40):773-777.

17. Kotlowitz A. There are no children here. New York: Doubleday; 1991.

18. Hawkins JD, Catalano RF, Brewer DD. Preventing serious, violent, and chronic juvenile offending. In: Howell JC, Krisberg B, Hawkins JD, Wilson JJ, eds. Serious, violent and chronic offenders. Thousand Oaks, CA: Sage Publications; 1996.

19. Sherman LW, Shaw JW, Rogan DP. The Kansas City Gun Experiment. In: The National Institute of Justice research in brief [pamphlet]. Washington, D.C.: U.S. Department of Justice; 1995.

20. Feldman LJ. Evaluating the impact of intensive family preservation services in New Jersey. In: Wells K, Biegal DE, eds. Family preservation services: research and evaluation. Newbury Park, CA: Sage; 1991. p. 47-71.

21. Widom CS. The cycle of violence. Science 1989;244(4901):160-166.

22. Dumas JE. Treating antisocial behavior in children: child and family approaches. Clin Psychol Rev 1989;9:197-222.

23. Patterson GR. Interventions for boys with conduct problems: multiple settings, treatments and criteria. J Consult Clin Psychol 1974;42(4):471-481.

24. Kazdin AE, Siegal TC, Bass D. Cognitive problem-solving skills training and parent management training in the treatment of antisocial behavior in children. J Consult Clin Psychol 1992;60(5): 733-747.
25. Zoline SS, Jason L. Preventive parent education for high school students. Journal of Clinical Psychology 1985;14: 119-123.

26. Patterson GR, DeBaryshe BD, Ramsey E. A developmental perspective on antisocial behavior. Am Psychol 1989;44(2): 329-335.

27. Krug EG, Brener ND, Dahlberg LL, Ryan GW, Powell KE. The impact of an elementary school-based violence prevention program on visits to the school nurse. Am J Prev Med 1997;13(6): 459-463.

28. Tolson ER, McDonald S, Moriarty AR Peer mediation among high school students: a test of effectiveness. Social Work in Education 1992;14:86-93.

29. McAlister A, Ama E, Barroso C, Peters $\mathrm{R}$, Kelder $\mathrm{S}$. Improving intergroup relations through students' behavioral journalism [conference presentation]. Carnegie Corporation meeting, Improving Intergroup Relations among Children and Youth, 17 October 1997, New York, New York.

30. Guerra NG, Tolan PH, Hammond WR. Prevention and treatment of adolescent violence. In: Eron LD, Gentry JH, Schlegel P, eds. Reason to hope: a psychosocial perspective on violence and youth. Washington, D.C.: American Psychological Association; 1994.

31. Organización Panamericana de la Salud. Prevención de la violencia: una oportunidad para los medios: memorias de la reunión de violencia y los medios de comunicación de Cartagena de 1996. OPS: Santafé de Bogotá, Colombia; 1998.

32. Vélez L. Let's talk, Cali [unpublished report]. Cali, Colombia: Centro de Investigaciones sobre Violencia y Salud, Universidad de Valle; 1997. 


\title{
RECONOCIMIENTO
}

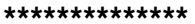

La Coordinación de Investigaciones de la División de Salud y Desarrollo Humano y el Programa de Salud Mental de la División de Promoción y Protección de la Salud de la Oficina Sanitaria Panamericana reconocen y agradecen la participación del Centro Colaborador de Promoción de la Salud de la Universidad de Texas en Houston, que propuso la idea inicial del proyecto ACTIVA y abrió los espacios de colaboración e intercambio con los investigadores de América Latina; del Instituto de Investigaciones Psicológicas de la Universidad de Costa Rica, que fungió como centro de referencia para el análisis de los resultados de las pruebas piloto y donde se realizaron talleres de trabajo con los investigadores para la construcción del cuestionario común; del Instituto de Estudios Sociales y de la Religión de Rio de Janeiro y del Programa de intercambio de investigadores de la Fundación Rockefeller, gracias a los cuales fue posible el arduo proceso de limpieza y compilación de las bases de datos y donde fueron recibidos los investigadores para realizar los análisis preliminares del estudio. Agradecen también al Departamento de Promoción de la Salud y del Comportamiento de la Universidad de Georgia la coordinación del trabajo de revisión de manuscritos y parte de la elaboración del material que constituye esta publicación; a Rodrigo Guerrero, cuya confianza y apoyo a los investigadores en momentos críticos fue decisiva y quien, con su liderazgo y experiencia, logró movilizar recursos científicos, técnicos y políticos que hicieron factible este estudio; a todos los investigadores y grupos nacionales que participaron y trabajaron en las diferentes fases del estudio y a las instituciones financiadoras en los palses. Finalmente agradecen el trabajo realizado por el grupo de expertos que revisó los manuscritos y especialmente a lleana Arias y Carlos Campillo por su minuciosa labor editorial.
\end{abstract}

\section{IN APPRECIATION}

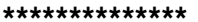

The Research Coordination Program of the Division of Health and Human Development and the Mental Health Program of the Division of Health Promotion and Protection of the Pan American Sanitary Bureau recognize and express thanks for the involvement of the Collaborating Center for Health Promotion Research and Development at the University of Texas-Houston, which proposed the initial idea for the ACTIVA project and made possible the cooperation and exchange with researchers from Latin America; the Psychological Research Institute of the University of Costa Rica, which served as a reference center in the analysis of the field test results and where workshops were held for researchers to develop the shared questionnaire; and the Institute of Social and Religious Studies of Rio de Janeiro and the Rockefeller Foundation research fellows exchange program, both of which made possible the arduous process of cleaning up and compiling the databases and hosted the researchers who carried out the preliminary analyses of the study. Thanks also go to the Department of Health Promotion and Behavior of the University of Georgia for coordinating the work of manuscript review and for part of the preparation of the material that makes up this publication; to Rodrigo Guerrero, whose confidence in and support of the researchers was decisive at critical moments and who, with his leadership and experience, managed to marshal scientific, technical, and political resources that made this study achievable; and all the researchers and groups in the countries that participated in and worked on the different phases of the study, as well as the institutions in the countries that provided funding. And last, recognition goes to the work done by the group of experts who reviewed the manuscripts, and especially to Ileana Arias and Carlos Campillo for their thorough editing efforts.
\end{abstract}

